\title{
迷走神経切離後の胃排出障害㳊関する実験的研究
}

\author{
東北大学医学部 檟外科教窒 \\ (主任 㮩 哲夫教授)
}

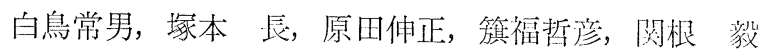

斉藤禎量, 長岡 梳, 加藤栄一, 横山成樹, 金子埥征

佐藤昭治

\section{AN ELECTROMYOGRAPHIC STUDY ON THE MECHANISM OF DELAYED GASTRIC EMPTYING AFTER VAGOTOMY IN THE DOG.}

Tsuneo Shiratori, Masaru Tsukamoto, Nobumasa Harada, Tetsuhiko Hatahuku, Takeshi Sekine, Teiryo Satto, Ken Nagaoka, Eiichi Kato, Shigeki Yokoyama, Yasuyuki Kaneko and Shoji Sato.

Department of Surgery, Tohoku University School of Medicine, Sendai

(Director; Prof. T. Maki)

To clarify the mechanism of delayed gastric emptying after vagotomy, and the related problem whether the vagotomized stomach develops pylorospasm under any condition, the author studied the motor function of the canine stomach with the use of electromyography when warm water was instilled before and after vagotomy.

Regardless of whether vagotomy had been performed or not, a marked excitation of the pyloric portion of the stomach occurred, resulting in a spasm-like abnormal excitation and anti-peristalsis as the intra-gastric pressure was risen by instillation of water. However, the vagotomized stomach required much more water than the non-vagotomized stomach to develop the same degree of excitation of the pyloric portion, and this difference was probably due to hypomotility or hypotonicity of the vagotomized stomach. On the other hand, vagotomy did not cause pylorospasm or abnormal excitation of the pyloric portion, although hypomotility of the stomach was present.

The above results suggested that the vagotomized stomach developed hypomotility or hypotonicity first, resulting in stasis and retention of the gastric content. And, the higher intra-gastric pressure due to this stasis and retention was followed by the occurrence of spasm-like abnormal excitation of the pyloric portion and anti-peristalsis. Therefore, "pylorospasm" was considered to occur secondarily as a result of gastric stasis and retention, but not primarily because of vagotomy.

\footnotetext{
緒論

従来より, 近側胃切除術, または分節的胃切除術を行 なった残胃，および十二指腸漬瘍に対する迷走神経切離 術を行なった胃において，術後胃内容の排出障害が起る ととは一般に知られている。乙の排出障害については幾 多の報告があり，迷走神経切離後に幽門症攣が起るた め1)2) とか，胃アトニーが起るため3-5) とか，またての両 者が共に起るため ${ }^{6)}$ とか種々考えられている。しかし， この排出障害は幽門痤攣または胃アトニーのみで起るも のかどうか，またての両者が共に起るとするならば，部 位を異にして同時に起るものか，あるいは時期を異にし て別々に起るものかどうか，てれら排出障害の発生機序

に関してはほとんど解明されていない。河野7), 白鳥ら8 は，迷走神経切離後には罥の蠕動運動の亢進や幽門部

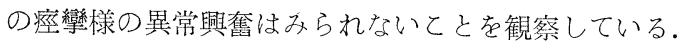
そこで著者らは，乙の排出障害の発生機序，乙とに迷走 神経切離後において, 胃に何らかの条件を加えた場合に 幽門㽷攣が起るかどうかを究明する目的で, イヌ胃を用 いて, 迷走神経切離前・後に胃内に微温水を注入した時 の胃運動を筋電図学的に観察した。その結果, 迷走神経 切離後に起る昌内容の排出障害の原因の 1 つとしてあげ られるいわゆる幽門㽷攣の発生機序について興味ある知 見を得た。
} 


\section{実 験 方 法}

実験動物としては $15 \mathrm{~kg}$ 前後の雑種成犬30頭を用いた。 24時間絶食させた後, $23 \sim 25^{\circ} \mathrm{C}$ の実験室において, thiopental sodium $(20 \mathrm{mg} / \mathrm{kg})$ の静脈麻陃下にイヌを背位 に国定し，正中切開にて開腹した。露出した胃幽門部前 壁の大弯側に沿って，固定用双極銀針電極を2 2 装着し， 罸活動電位を導出した。電極の装着部位は，1コは幽門 輪より $1 \mathrm{~cm}$ 近側位，他の 1 コはその電極よりさらに $3 \mathrm{~cm}$ 近側位とした（図 1)．筋電計は三栄測器製万能筋電計 を用い，記録には三栄測器製ペン書き式記録器を使用し た (時定数; 0.1 秒). 迷走神経切離は, 人工呼吸器の 使用のもとに, 左第 8 肋間で開胸し, 横隔膜直上にて前

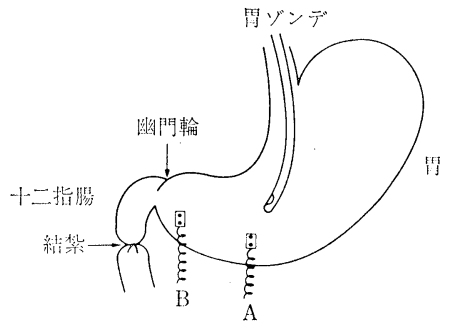

$$
\begin{aligned}
& \text { A, B : 電極 } \\
& \text { 幽門輪一B : } 1 \mathrm{~cm} \\
& \mathrm{~A}-\mathrm{B} \quad \text { : } 3 \mathrm{~cm}
\end{aligned}
$$$$
\text { 図1。実験方法 }
$$

後の迷走神経幹を切離し，他に胃に向う分枝のないとと を確認して完全なものとした。また，微温水注入用の胃 ゾンデを経口的に胃内に挿入し，胃内微温水の流出を防 ぐために幽門輸から約 $10 \mathrm{~cm}$ 肛門側で十二指腸を絹糸に て結紮，閉鎖し（図 1），また，ての注入微温水が食道 に逆流しないように実験台を25度傾斜せしめ頭部高位と した。注入用微温水の温度は $37 \sim 38^{\circ} \mathrm{C}$ とした.

ついで, $200 \mathrm{ml}$ の微温水を 30 秒で注入し，約 30 分お いて再び $200 \mathrm{ml}$ 注大し, $200 \mathrm{ml}$ 単位に $1,000 \mathrm{ml}$ までて れをくりかえして, 総計 $1,000 \mathrm{ml}$ まで胃内に注入, こ

\section{実験}

\section{I) 迷走神経切離前}

A）微温水注入前：無処置時においては肉眼的に微 弱な正蠕動運動が認められ，筋電図学的には正蠕放電の 放電間隔は 15.6 秒，伝播速度は $12.5 \mathrm{~mm} / \mathrm{sec}$ であっ た。逆蠕動放電の出現は非常に少なく, その発生頻度は 平均で $0.5 \%$ であった（図3，表1，2，3）.

B) 微温水注入後 : つぎに微温水を $200 \mathrm{ml}$ 胃内に注 入すると, 注入前に比べて肉眼的には著変がなかった が，正蠕動放電の放電間隔は 16.8 秒とや〉延長を示 し，その伝播速度も $15.0 \mathrm{~mm} / \mathrm{sec}$ と増大した。逆蠕動
の操作を迷走神経切離前・後に行ない，乙の間における 胃運動の変化を筋電図学的ならびに肉眼的に観察した。

一般に筋電困学的には, 胃蠕動運動が方進してくるに つれて, 蠕動放電の放電間隔が延長して伝播速度が速く なるとと、および幽門部の異常興舊時には逆蠕動放電が 高頻度に出現してくるととが知られている9). また逆 に, 臨床的にも, 幽門部に逆蠕動がみられるような場合 には, 疘箏様の強い蠕動運動が観察され, 胃内容の十二 指腸への排出が障害されるととは知られている10). この ような観点から, 著者らは，いわゆる幽門㾏䛓の判定基準 として逆蠕動放電の頻発を, 蠕動六進の判定基準として は放電間隔の延長扣よび伝播速度の増大を示標とした。 な打筋電図については, 正蠕動放電の放電間隔, 伝播速 度打よび逆蠕動放電の発生頻度について分析した。乙れ らはいずれも，30 例において各期の微温水注入直後か ら約 30 分間に記録された筋電図のうち50 コの蠕動放電 によるものであり，30 例の平均值について検討した。

また，正蠕動放電と逆蠕動放電の識別は，近側の電極 $\mathrm{A}$ より先に活動電位が得られた場合を正蠕動放電とし, 逆 に遠側の電極 Bより先に活動電位が得られた場合を逆 蠕動放電とした（図 2). また各注入期の肉眼的および筋 電図学的所見の比較は, 直前の注入期の所見に対して行な ったものである。
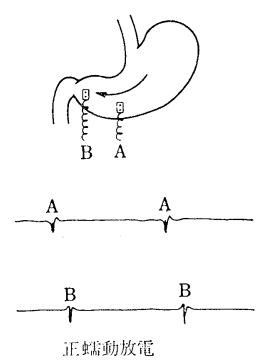

図 2. 正蠕動放電と逆蠕動放電の識别
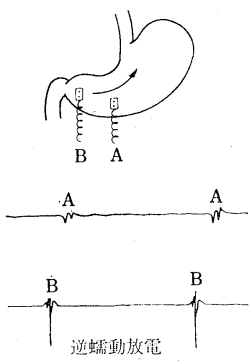

B

\section{成 績}

放電は少なく，その発生頻度は僅かに $5.0 \%$ を示した に過ぎなかった。 $400 \mathrm{ml}$ 注入時になると, 軽度の胃拡張 とともに蠕動運動もや〉増強し, 正蠕動放電の放電間隔 は 16.5 秒と著変をみなかったが, 伝播速度は $15.5 \mathrm{~mm} /$ secとや〉速くなり, 逆蠕動放電の発生頻度も $28.5 \%$ と 増大した。 $600 \mathrm{ml}$ 注入時になると; 胃全体の著明な拡張 と強い蠕動運動が見られ，正蠕動放電の放電間隔は 17.7 秒と著しい延長を示したが，その伝播速度は $16.0 \mathrm{~mm} /$ sec と軽度の増大を示した。逆蠕動放電も頻発するよう になり. $40.5 \%$ に認められた. $800 \mathrm{ml}$ 注入時では, さら 


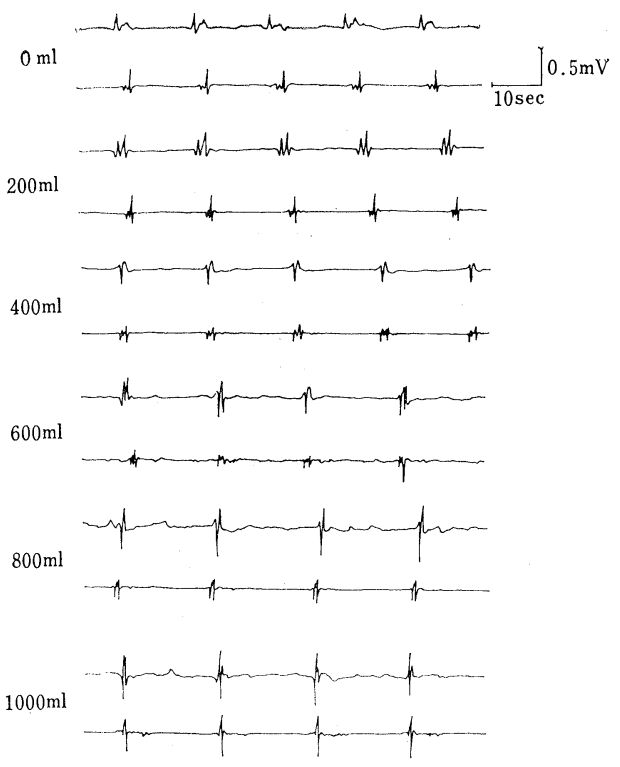

図 3. 迷走神経切離前における断温水注入時胃筋電図

表 1. 正蠕動放電の放電間隔 (平均值)

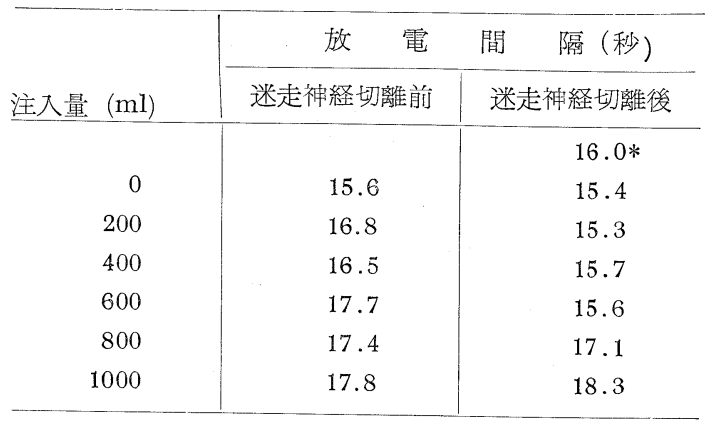

*：迷走神経切離直前

表 2 . 正蠕動放電の伝播速度 (平均値)

\begin{tabular}{r|c|c}
\hline \multirow{3}{*}{ 注入量 $(\mathrm{ml})$} & 伝 播 速 & 度 $(\mathrm{mm} / \mathrm{sec})$ \\
\cline { 2 - 3 } & 迷走神経切離前 & 迷走神経切離後 \\
\hline & & $12.5 *$ \\
200 & 12.5 & 11.5 \\
400 & 15.0 & 13.0 \\
600 & 15.5 & 13.5 \\
800 & 16.0 & 16.0 \\
1000 & 19.5 & 17.5 \\
\hline
\end{tabular}

* : 迷走神経切離值前

に胃拡張が著しくなり，強い正および逆蠕動運動が観察 された。正蠕動放電の放電間隔は 17.4 秒と $600 \mathrm{ml}$ 注 入時よりや〉短縮したが, 伝播速度は $19.5 \mathrm{~mm} / \mathrm{sec}$ と著
表 3 . 逆蠕動放電の発生頻度 (平均值)

\begin{tabular}{|c|c|c|}
\hline & 発 生 & 度 $(\%)$ \\
\hline 注入量 $(\mathrm{ml})$ & 迷走㖄経切離前 & 迷走神経切離後 \\
\hline & & $0 *$ \\
\hline 0 & 0.5 & 0 \\
\hline 200 & 5.0 & 1.5 \\
\hline 400 & 28.5 & 8.5 \\
\hline 600 & 40.5 & 20.5 \\
\hline 800 & 49.0 & 39.0 \\
\hline 1000 & 42.0 & 43.0 \\
\hline
\end{tabular}

しく増大し, 逆蠕動放電の発生頻度も $49.0 \%$ と著明な増 加をみた。しかし， $1,000 \mathrm{ml}$ 注入時になると，胃拡張は 著しかったが蠕動運動は $800 \mathrm{ml}$ 時に比べてや〉減弱し た. 正蠕動放電の放電間隔は17.8秒と延長を示したが， 伝播速度は $17.0 \mathrm{~mm} / \mathrm{sec}$ とや減少し, 逆蠕動放電も 42.0\%とわずかに減少した（図3，表1，2，3）。

ついで，胃内に注入した微温水を胃ゾンデより吸引し て胃を空にし，30〜40 分後に観察すると，正蠕動放電 の放電間隔は 16.0 秒，伝播速度は $12.5 \mathrm{~mm} / \mathrm{sec}$ で逆蠕 動放電の出現は全く認められず，はぼ微温水注入前の所 見に回復するのがみられた（図4，表1，2，3）。

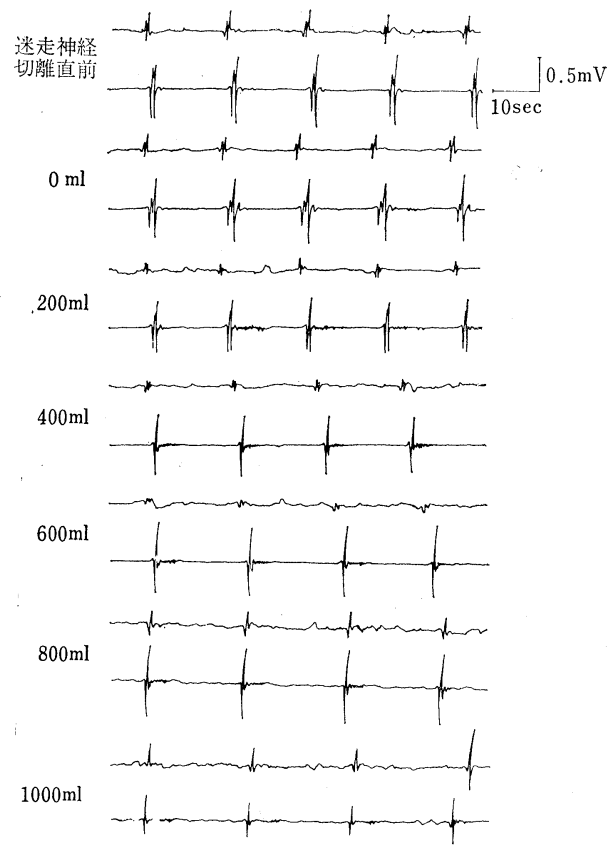

図 4. 迷走神経切離後における微温水注入時胃筋電図

つまり，迷走神経切離前においては，微温水の注入量 を増して胃内圧を高わると，胃の蠕動運動は次第に六進 
し，とくに幽門部の興舊は著明となり，ついには幽門部 に噔攣様の異常興舊が見られ, 逆蠕動の頻発をきたし た.

\section{II) 迷走神経切離後}

A）微温水注入前：迷走神経切離後約 40分間の観察 では，迷走神経切離直前と比べて肉眼的にはほとんぞ変 化がみ弓れなかった，筋電图上では，正蠕動放電の放電 間隔は15。4秒と切離前に比べてわずかに短縮し, その伝 播速度も $11.5 \mathrm{~mm} / \mathrm{sec}$ とや減少した。逆蠕動放電は 30 例飞拀いて全く認邓られなかった（図4，表1，2，3）。

すなわち，迷走神経切離それ自体では幽門痓攣または 幽門部の異常興舊はみられず，むしろ胃運動の減弱がみ られた。

B) 微温水注入後：て〉で再び微温水を $200 \mathrm{ml}$ 注入 すると, 注入前に比べて肉眼的にはわずかに強い正蠕動 運動が見られたが，筋電図上では正蠕動放電の放電間隔 は 15.3 秒と著変がなかった。伝播速度は $13.0 \mathrm{~mm} / \mathrm{sec}$ とわずかに増大したが，逆螨動放電は非常に少なく，そ の発生頻度は $1.5 \%$ であった. $400 \mathrm{ml}$ 注入時において は, 蠕動運動は $200 \mathrm{ml}$ 注入時に比べて著変が認められ ず，正蠕動放電の放電間隔も 15.7 秒と余り変化がなか った。伝播速度は $13.5 \mathrm{~mm} / \mathrm{sec}$ とや〉増大したが，逆 蠕動放電の発生頻度は $8.5 \%$ 亿過ざなかった。 $600 \mathrm{ml}$ 注 入時では胃抎張とや〉強い蠕動運動が見られ, 正蠕動放 電の放電間隔は 15.6 秒と著変をみなかったが，その伝 播速度は $16.0 \mathrm{~mm} / \mathrm{sec}$ と増大した。逆蠕動放電の発生頻 度も $20.5 \%$ と軽度增大を示した. $800 \mathrm{ml}$ 注入時になる と, 胃抎張は著明になり, 強い正蠕動運動に混って逆蠕 動運動が高頻度に出現するのがみられた。正蠕動放電の 放電間隔は 17.1 秒と著明な延長を示し, 伝播速度も $17.5 \mathrm{~mm} / \mathrm{sec}$ と著しく増大した。逆蠕動放電も $39.0 \%$ と高頻度を示した。 $1,000 \mathrm{ml}$ 注入時においては， $800 \mathrm{ml}$ 注入時よりさらに著明な胃拡張と強い正および逆蠕動運 動が見られ，正蠕動放電の放電間隔は 18.3 秒とさらに 延長を示し，伝播速度も $20.0 \mathrm{~mm} / \mathrm{sec}$ と最高值を示し た。また逆蠕動放電の発生頻度も， $43.0 \%$ と著しく堌 大した（図 4，表1，2，3）.

つまり, 迷走神経切離後においても切離前と同様, 微 温水の注入量を增して胃内圧を高好々, 蠕動運動の元 進，幽門部の率攣様の異常興奮および逆蠕動の頻発をる たした。しかし，一般に同量の胃内容では迷走神経切離 前よりも，切離後の方が蠕動運動の元進および幽門部の 興奞性は低い傾向がみられた。

以上の実験成績を総括するとつぎの通りである.

迷走神経切離を行なう行なわない汃わらず, 胃内 の注入量を増して胃内圧を高めると, 胃の蠕動運動は次 第に亢進するが，とくに幽門部で興奮は著明となりつ いには痤攣様の異常興蓞がみられ，逆蝶動の頻発をきた
すようになる。

しかしながら, ての所見を迷走神経切離前と切離後に ついて詳細に比較検討してみると, 興奮の起り方に若干 の差異がある(図 5, 6,7).すなわち, 正蠕動放電の放電 間隔は, 迷走神経切離前では $600 \mathrm{ml}$ 以上で著明な延長を 示したのに対し，切離後では $800 \mathrm{ml}$ 以上で同程度の延長 を示すというズレが見られた。正蠕動放電の伝播速度に おいても, 切離前は $800 \mathrm{ml}$ で切離後は $1,000 \mathrm{ml}$ で最も 速くなるというズレがみられた。 また逆蠕動放電の発生 頻度も同様に，切離前では $600 \mathrm{ml}$ 以上で，切離後は 800

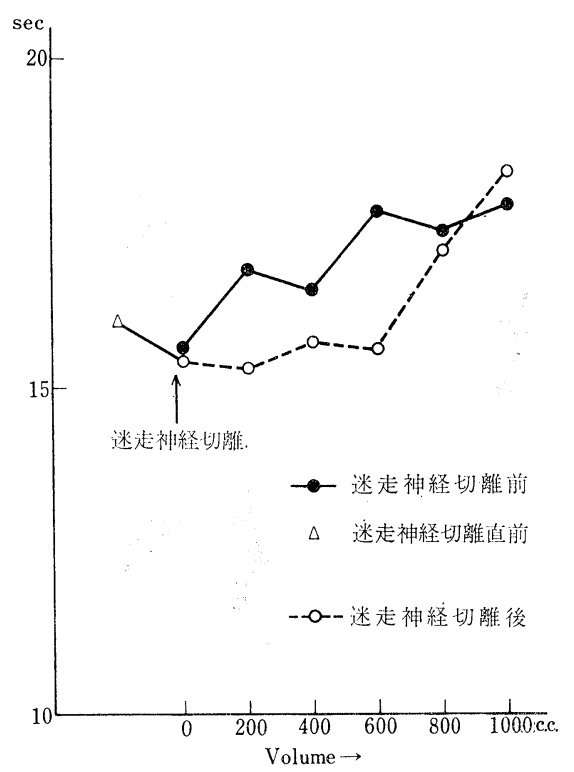

図 5。正蠕動放電の放電間隔（平均值）

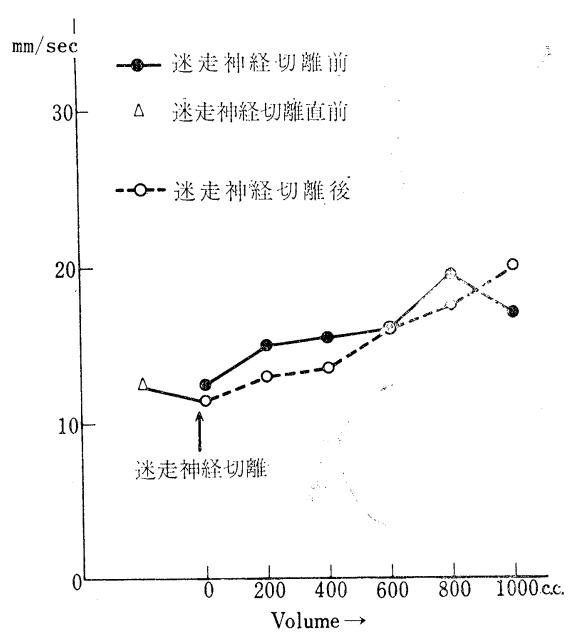

図 6. 正䇕動放電の伝播速度（平均値） 


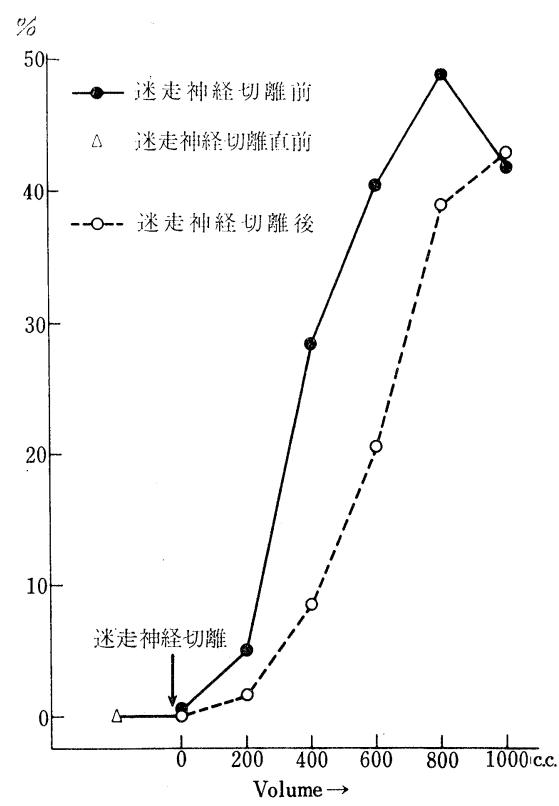

図 7. 逆蠕動放電の発生頻度（平均值）

\section{考}

迷走神経切離後の胃の運動機能についてはいくつかの 問題点があるので，てれらの点について若干の検討を加 えてみる.

まず第一に，幽門痤攣という意味について検討してみ る. 多数の臨床報告 $1,2,6)$ ので, 迷走神経切離後には幽 門痤卛が起ると述べられているが，乙の幽門痤攣は生理 学的な筋の spasm を意味するものか，あるいは生理学 的な意味の spasm ほどではないが高度に運動機能の立 進した状態を指すものかについては説明がなされてい ない，著者らの成績および著者らの教窒の臨床経験によ れば，確かに生理学的な意味の spasm がないとはいえ ないにしても，ほとんどの例においてそのような spasm をみるてとはない。すなわち，臨床において，幽門痤攣 とされているものの大部分は，幽門部の興奮が異常に高 まって強い収縮が起てり，胃内容を十二指腸に排出でき なくなるような状態を指しているものと思われる。した がって, 迷走神経切離後の幽門痓攣には, 生理学的な意 味のものと，臨床的な意味のものの画方が含まれている ように思われるので，本論文では臨床的な意味の場合 に対し，いわゆる幽門㾐攣という言葉を用いた。

つぎに，著者らはいわゆる幽門㾐攣の示標として，筋 電図学的に逆蠕動放電の発生頻度を用いたが，乙の問題 について検討してみる.著者らの教室では，イヌを用い た筋電図学的実験9)において，胃幽門部の興奮性が異常 に高まると逆蠕動放動が出現するとと, また逆に, 逆蠕 動放電が頻発するような場合には，幽門部には異常に興 $\mathrm{ml}$ 以上で著明に高くなるというズレを示した。このと とは，胃内容を増してほぼ同じ程度の興奮を起させるに は，切離後の方加切離前よりも多星の胃内容を必夏とす るととを示すものであり，迷走神経切離によって㖰運動 機能の減弱ないしは型壁のトーヌスの減弱が起るためと 解される.

また迷走神経切離それ自体では幽門㾏攣または幽門部 の異常興舊はみられず，むしろ蠕動運動の減弱がみられ る.

以上の所見を総合すると，迷走神経切離後にはまず胃 運動機能の減弱ないしは胃壁のトーヌスの減弱が起り, このために胃内容の停满，貯溜が起る。乙の胃内容の貯 溜が高度になってくると胃内王の㠵進が著明となり，そ の結果として幽門部の運動機能が異常に九進し, 痤攣様 の異常興奮や逆蠕動の頻発をみるに至るものと推祭され る.したがって，いわりる幽門痤攣は迷走神経切離の一 次的結果として起るものではなく，胃内容の貯溜後二次 的に起るものと考えられる。

\section{按}

舊した蠕動運動がみられるととを観察している。また臨 床的にも, 近側胃切除術や分節的胃切除術を行なった後 の残胃のレ線学的観察10)において, 幽門部の蠕動運動が 著明に京進して異常興奮が起てり, 胃内容の排出遅延が みられるととが観察されているが，乙の際には胃に逆蠕 動が出現すると報告されている.

とのような観点から，著者らは逆蠕動放電をいわゆる 幽門痤攣の示標としたが，乙のような観察方法は他に例 をみないととであり, 逆蠕動の意義といった点で, 大方 の意見を仰ぎたい.

最後に, 本論文の主題である迷走神経切離後の胃内容 の排出障害の機序，乙とに迷走神経切離後には果して幽 門痓攣が起るものか，あるいは胃アトニーが起るもの か，またての両者がいかなる関係のもとに起ってくるも のかについて検討を加えてみる。

Carlson \& Litt ら 11) は，バルーンを用いてイヌの胃幽 門部の内圧を測定した実験から，迷走神経は胃幽門部に 対し運動促進と運動抑制の両線維を送っており，したが って頸部で迷走神経切離を行なうと, 幽門部の運動機能 が抑制されるとともあるが，逆に幽門部のトーヌスが増 強するとともあると述べている。また Dragstedt は， 迷走神経切離後には幽門括約部のトーヌスが増強すると いう古い見解は，臨床経験とよく合うと述べ 12)，また 別の報告において迷走神経は一般に胃幽門部および胃噴 門部に対しては運動抑制的に，胃体部に対しては運動促 進的に作用するといわれているととを述べている13). し 
かしとの点について,著者らの成績および教室の河野 7)， 白鳥ら ${ }^{8)}$ の報告においては，迷走神経幹を切離した場 合, 筋電図学的および肉眼的に 1 例も幽門部の運動機能 の亢進例をみていない.したがって，もし迷走神経に運 動促進と運動抑制の両線維があるとしても，迷走神経幹 を切離した場合には運動促進線維の切離の影響が強く現 れるととが考えられ，Carlson \& Litt らの報告には疑問 が持たれる。また Dragstedt ら ${ }^{13)}$ の報告にみられるよ うに，迷走神経は胃幽門部の運動機能に対して抑制的に 作用するという一般的な考方詨しては，著者らの成 績では迷走神経の胃幽門部に対する抑制效果の所見を全 く得ておらず，一概に賛成できない。また，Franke \& Ney ${ }^{1)}$ も，噴門癌に対する近側胃切除術後の残胃の運動 機能についての報告の中で, 迷走神経切離後には幽門痤 攣が起ると述べている。しかし，てれについては，白鳥 ら ${ }^{8)}$ は胃を横切離した場合にみられる幽門部の蠕動運動 の異常亢進は迷走神経切離によるものではなく，胃壁の 横切離によるものであることを指摘している.

これらの説に対して, 迷走神経切離後には胃の運動機 能が減退するとか，胃壁のアトニーが起るとする説があ る. Weinberg ${ }^{3)}$ は，十二指腸潰瘍に対する迷走神経切 離術および幽門成形術についての論文において，迷走神 経切離後には胃平滑筋の収縮力およびトーヌスが減弱す るために胃内容の排出遅延が起ると述べている. Wood$\operatorname{ward}^{4)}$ も，迷走神経切離術および幽門成形術を行なった 後の幽門洞部の分泌機能についての論文の中で，迷走神 経切離後には胃の運動機能が減弱し, 食物や消化液の貯 溜が起ると述べている。また Nelsenら ${ }^{14)}$ は, イヌ青を 用いた筋電図学的研究において, 胃内容の十二腸への排 出時間を測定し，迷走神経切離後は正常時に比べて，よ り長時間幽門輪が開口していると述べている. Paulson \& Gladsden ${ }^{15)}$ も，臨床例における胃鏡所見から，迷走 神経切離後には胃は弛緩性に拡張して蠕動が見られず， 幽門輪が持続的に広く開口しているととを観察し，胃 体部と胃幽門部が自律神経により反対に支配されるとい う説は再検討を要すると述べている。また，ての Paul son \& Gladsden の報告に基づいて, 迷走神経切離後 には幽門痤攣が起らないと考えている人もいるようであ る.しかし，てれらの所見だけから，迷走神経切離後に 幽門㾏攣が起らないといえるであろうか。なぜなら，迷 走神経切離後の胃に何らかの条件が加えられた場合でも 幽門症攣が起らないかどうかというととについては，て れらの論文では触れていないからである，確かに著者ら の成績からも，迷走神経切離それ自体では幽門痤攣は起

\section{結}

迷走神経切離後に見られる胃内容の排出障害の発生機 序, ことに迷走神経切離後に幽門㾏攣が起るかどうか,
らず，むしろ胃運動機能の減弱をみている。しかしなが ら, 迷走神経切離後においても, 胃内容を増して胃内圧を 高めるという条件が加えられれば，幽門部に病攣様の異 常興舊が起るととを著者らの成績は明らかにしている. ての点 Nissen $\left.{ }^{6}\right)$ は, 食道, 胃吻合術後の障害に関する 臨床例の報告に扑いて, レ線学的観察汃ら, 迷走神経切 離後には胃アトニーと幽門病攣が起てり，乙のために排 出が障害されると述べている。しかしての論文では，胃 アトニーと幽門㽷攣の雨方が共に起るととを述べてはい るが，との両者の関係，ととにとの両者蔀位を異にし て同時に起るものか, あるいは時期を異にして別々に起 るものかについては，全く述べていない。

以上のように, 迷走神経切離後には単に幽門痓攣が起 ると文，あるいは胃アトニーが起るとか，また幽門痤攣 と胃アトニーの両方が起るとか種々の報告があるが，釈 然としない多くの問題が含まれているように思われる. すなわち, 著者らの成績汃らいと, Paulson \& Glads$\operatorname{den}^{15)}$, Nelsen ${ }^{14)}$, Weinberg ${ }^{3)}$ およびWoodward $^{4}$ ) らの, 迷走神経切離後には䏴アトニーが起るとする説, および Dragstedt ${ }^{12)}$, Franke \& Ney ${ }^{1)}$, および Nissen ${ }^{6}$ ) らの幽門部のトーヌスの増強や幽門痤攣が起るとする説 はいずれも正しいと思われる。しかし，てれらの報告で は運動機能の面からただ単に興奮または減退といった全 く相反した観察がなされているととについては，説明さ れていない，ての点著者らは，迷走神経切離それ自体で は幽門痓攣は起らず，むしろ胃運動機能の減弱ないしは 胃アトニーが起るが，そこに胃内容の停滞，貯溜などの 条件が加えられるならば，迷走神経切離後でもいわゆる 幽門㾏攣が起しるととを明らかにした。したがって，迷 走神経切離後に見られる胃内容の排出障害の機序はつぎ のように推察される.つまり, 迷走神経切離によってま ず青の運動機能の減弱ないしは胃アトニーが起り，この ために胃内容の停滞, 貯溜による胃内圧の古進をきた し，その結果として二次的に幽門部に痤攣様の異常興奮 および逆蠕動の発生をきたして胃内容の排出がますます 障害される.

との著者の考え方からすると，今までに観察された迷 走神経切離後の幽門㾏攣，あるいは胃アトニー，および 胃内容の排出障害の機序はいずれも釈然として来るよう に思われる.

著者の成績は, 臨床上極めて重要な示唆を与えるもの と思われたので，今後慢性実験を行ない，さらに報告す る考えである。

\section{語}

起るとすればどのようにして起るかを究明する目的で, 迷走神経切離前, 後において, イヌ胃内に微温水を注入 
して胃内压を高めたときの胃運動を肉眼的ならびに筋電 図学的に钼察し，つぎの結果を得た。

1）迷走神経切離を行なう行なわないにかかわらず,

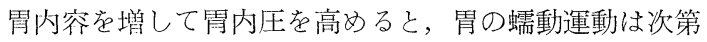
に艺進し，とくに幽門部で興奮は著明となり，ついには 痤攣様の異常興舊, および逆蠕動の頻発を来して, いわ ゆる幽門㽷攣が出現するようになる。

2）胃内容を増してほぼ同じ程度の幽門部の興奪を起 させるには, 迷走神経切離後の方が切離前よりも多量の 胃内容を要する。とのととは，迷走神経切離によって胃 アトニーが起るためと解される。

3）迷走神経切離それ自体では幽門痤攣または幽門部

\section{文}

1) Franke, H. \& Ney, H.R. : Die Chirurgi des Kardiacarcinoms, ein Problem der Frühdiagnose und der Reflexoesophagitis. Chirurg., 30, 152-157, 1957.

2) Stein, I.F. \& Meyer, K.A.: Studies on vagotomy in the treatment of peptic ulcer. Surg. Gynec. Obstet., 86, 473-479, 1948.

3) Weinberg, J.A.: In Harkins, H.N. \& Nyhus, L.M. (editors): Surgery of the stomach and duodenum, p. 473-486, Little, Brown and Company, Boston, 1962.

4) Woodward, E.R.: Hyperfunction of gastric antrum following vagotomy and pyloroplasty. Arch. Surg., 77, 289-293, 1958.

5) Tanner, N.C.: Neue Problem der Magenchirurgie. Langenbecks Arch. klin. Chir., 267, 369-373, 1951 .

6) Nissen, R.: Funktionelle und organische Störungen nach gastro-ösophagealen Anastomosen. Helv. Chir. Acta, 19, 314323, 1952.

7) 河野兵衛：筋電図学的立場から見た胃支配神経 切断時の骨機能. 東北医誌, 65, 547-558, 1962.

8) Shiratori, T. et al.: Effect of vagotomy or splanchnicectomy on the motility of the
の異常興奮はみられずむしろ胃運動機能の娍弱心シみら れる。

4) いわめる㗀閒痤攣は迷走神経切離の一次的結果と して起るものではなく, 迷走神経切離によって起る胃ア トニ一に基づく, 胃内容の停滞, 貯溜による胃内圧の亢 進の結果として二次的に起る.

5）以上の成績より，迷走神経切離後に見られる胃内 容の排出障害は，迷走神経切離によってまず罱アトニー が起り, ついで胃内容の停滞, 貯溜による筒内代の元進 を来し, その結果として二次的に, 幽門部に痤攣様の異 常興奮および逆蠕動の発生を来し，胃内容の排非がます ます障害されるものと推察される。

献

canine stomach with transection-anastomosis. Tohoku J. exp. Med., 93, 317-329, 1967.

9) 白鳥常男：槙哲夫，鈴木泰三 (編) : 平滑筋笳 電図の基礎と臨床, 180-186頁, 金原書店, 東京, 1966.

10)白鳥常男：外科的見地から見た胃の病態生理， 特に運動機能を中心として. 日平滑筋誌，2，1一 14, 1966.

11) Carlson, A.J. \& Litt, S.: Studies on the visceral nervous system. Arch. intern. Med., 33, 281-291, 1924.

12) Dragstedt, L.R.: Vagotomy in the surgical treatment of peptic ulcer. Surg. Clin. N. Amer., 46, 1153-1162, 1966.

13) Dragstedt, L.R. et al.: Section of the vagus nerves to the stomach in the treatment of peptic ulcer. Ann. Surg., 126, 687-708, 1947.

14) Nelsen, T.S. et al.: Alterations in muscular and electrical activity of the stomach following vagotomy. Arch. Surg., 94, $821-835,1967$.

15) Paulson, M. \& Gladsden, E.S.: Gastroscopic appearances following vagotomy. J. Amer. Med. Ass., 139, 151-152, 1949. 